\title{
Symbicort SMART išplečia astmos kontrolès galimybes
}

\author{
Prof. habil. dr. Brigita Šitkauskienè \\ KMU Pulmonologijos ir imunologijos klinika
}

Reikšminiai žodžiai: astmos kontrolè, Symbicort SMART, paūmèjimai, rizika ateityje.

Santrauka. Naujausios astmos gydymo rekomendacijos nurodo, kad gydymas turètų užtikrinti ne tik esamą kontrolę, bet ir sumažinti su liga susijusią riziką ateityje. Retrospektyvioji astmos klinikinių tyrimų analizė rodo, kad gydant Symbicort SMART metodu pavyksta ne tik pasiekti gerą astmos kontrolę, bet ir reikšmingiau sumažinti astmos paūmèjimų dažnumą nei gydant tradiciniu metodu, - taip išplečiamos galimybės kontroliuoti astmą.

Astma yra viena dažniausių lètinių ligų, kuria serga maždaug $300 \mathrm{mln}$. pasaulio gyventojuc, t. y. apie 4,4 proc. populiacijos. Astmos paplitimas sparčiai didejja dèl šiuolaikinio gyvenimo būdo ir urbanizacijos. Statistikos duomenimis, per pastaruosius 10 metu sergamumas astma Vakaru Europoje padidejo du kartus. Apskaičiuota, kad 2025 metais pasaulyje sergančiųju astma gali būti $400 \mathrm{mln}$., jei ir toliau laikysis tokios pačios tendencijos. Nepaisant šiuolaikinių astmos diagnostikos ir gydymo metodų, pasaulyje per metus nuo astmos miršta vidutiniškai 250 tūkst. žmonių. Taigi astma - aktuali problema, reikalinga naujo požiūrio i

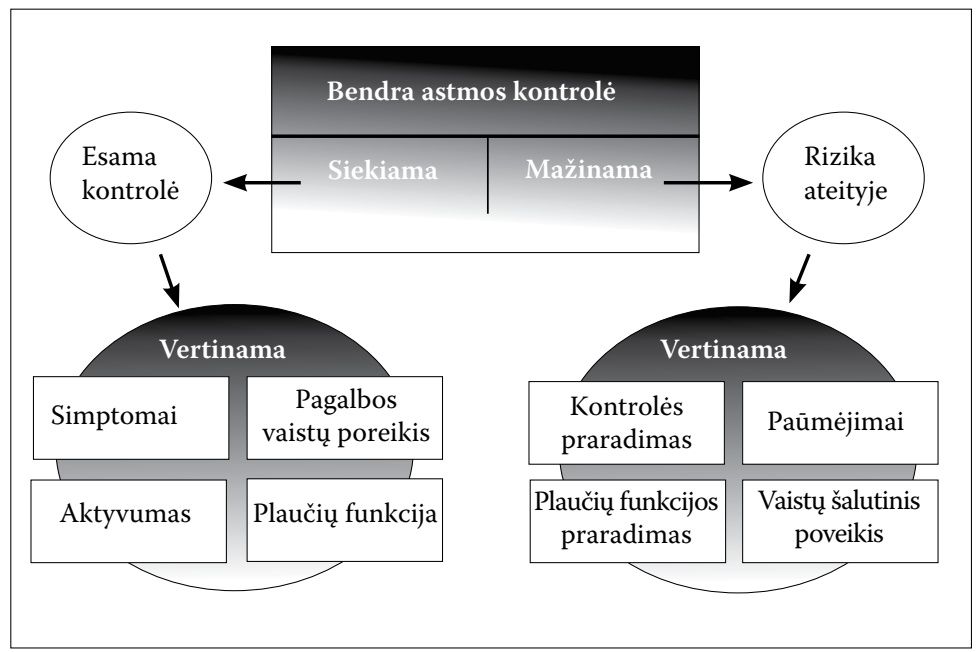

1 pav. ASTMOS GYDYMO TIKSLAI gydymą, kuris turètų būti veiksmingas, saugus ir pritaikytas pagal ligos eigos ypatumus.

\section{ASTMOS KONTROLĖS SAMPRATA}

Neseniai paskelbtose Pasaulio astmos gydymo ir profilaktikos strategijos (GINA) komiteto rekomendacijose ir Amerikos torakalistu sąungos/Europos respiratologu sąjungos parengtame dokumente pateikiamas papildytas astmos kontrolès apibūdinimas (1 pav.). Kaip ir kitų lètinių ligu atvejais, astmos kontrolès apibrèžimas apima ne tik esamą kontrolę, bet vẻlyvuosius ilgalaikius kontrolès komponentus - „riziką ateityje“. Esama kontrolè vertinama atsižvelgiant i klinikinius simptomus ir funkcinę būklę. Vertinant ateities riziką, dèmesys kreipiamas i šiuos dalykus: paūmèjimų riziką, nestabilumą (pasikartojančius netinkamos kontrolès epizodus), išliekančią blogesnę plaučių funkciją, vartojamų vaistų šalutinị poveikį.

Daugelio lètinių ligų, kaip antai cukrinio diabeto, arterinès hipertenzijos, svarbiausias gydymo tikslas užtikrinti, kad apibrèžta ligos kontrolè sumažintų komplikacijų riziką ateityje. Tokiam ryšiui tarp esamos astmos kontrolès ir rizikos ateityje anksčiau buvo teikiama mažai dèmesio. Astmos paūmejjimai, kai reikia hospitalizuoti ar net mirtini, yra svarbiausi rizikos ateityje kriterijai, o nestabili astmos eiga, atspindinti blogą ligos kontrolę, susijusi su blogèjančia gyvenimo kokybe ir psichosocialiniais bei ekonominiais padariniais. Be to, kai kuriems sergantiesiems astma gali 
sparčiau blogèti plaučių funkcija, tai vadinamoji „remodeliacija“.

Šiandien abejonių nekelia, kad svarbiausias astmos patogenezès mechanizmas - nuolat persistuojantis uždegimas kvėpavimo takuose, o inhaliuojamieji gliukokortikoidai (IG) yra pagrindiniai vaistai, veiksmingiausiai slopinantys šị uždegimą. İrodyta, kad pacientams, kuriems nepavyksta kontroliuoti astmos mažomis IG dozèmis, papildomai, bet tik kartu su IG, skiriant ilgai veikiančių inhaliuojamųjų beta 2 agonistų (IVBA salmeterolio arba formoterolio) sumažèja simptomų, gerejja plaučių funkcija, suretėja astmos priepuoliai, t. y. astma tampa geriau kontroliuojama. Vartojant minètų grupių vaistu sudetinius preparatus: flutikazono ir salmeterolio (Seretide , „GlaxoSmithKline“) bei budezonido ir formoterolio (Symbicort ${ }^{\circ}$, „AstraZeneca“), pasireiškia jų adityvinis poveikis, leidžiantis sumažinti IG dozę, sèkmingiau koreguojamas astmos patofiziologinis procesas bei greičiau pasiekiama astmos kontrolè. Sudètiniai šių vaistų preparatai garantuoja abiejų vaistų molekulių patekimą i kvėpavimo takus vienu metu, jie patogūs vartoti ir pagerina vaistu vartojimo nurodymų vykdymą.

GOAL (angl. Gaining Optimal Asthma ControL) klinikinis tyrimas parodè, kad gydant astmą (flutikazonu ir salmeteroliu) pakopiniu būdu pagal kontrolès kriterijus didelei daliai pacientu pavyko pasiekti gerą ligos kontrolę, - 74 proc. dienų be astmos simptomų. Tačiau žinoma, kad astmos eiga yra kintama, priklauso nuo ìvairių veiksnių: virusinių infekcijų, alergenų ir kt., galinčių sukelti paūmèjimus. $2005 \mathrm{~m}$. publikuoti INSPIRE tyrimo duomenys rodo, kad net ir tu pacientú, kurių astma gerai kontroliuojama, būklè vertinant pagal astmos kontrolès klausimyną (ACQ) pablogèja vidutiniškai 7 kartus per metus. Tai rodo, kad astmos gydymas turètų būti lankstesnis, pritaikytas prie šių ligos eigos ypatumų.

\section{SYMBICORT SMART METODAS}

Klinikiniais tyrimais nustatyta, kad formoteroli ir budezonidą viename inhaliatoriuje galima skirti ne tik ilgalaikiam nuolatiniam astmos gydymui, bet ir papildomai simptomams šalinti (vietoj trumpai veikiančiu beta 2 agonistu (TVBA)). Tokia gydymo metodika pavadinta SMART (angl. Single inhaler for maitenance and relief therapy) ir yra patvirtinta daugelyje pasaulio šalių astmai gydyti. Klinikinių tyrimų duomenimis, gydant Symbicort SMART metodu pavyksta pasiekti ne tik gerą astmos kontrolę, bet ir sumažinti astmos paūméjimų (privalumas lyginant su kitais gydymo būdais). Be to, ši metodika sudaro galimybę veiksmingai kontroliuoti astmą mažesnèmis IG dozèmis ir taip sumažinti galimą vaistų šalutini poveikị. Atliktuose tyrimuose šio gydymo rezultatai buvo lyginti su gydymu didesne palaikomąja budezonido doze, arba tokia pačia ar didesne IG/IVBA doze kartu skiriant TVBA pagal poreiki simptomams šalinti, kaip ir GOAL tyrime $(2$

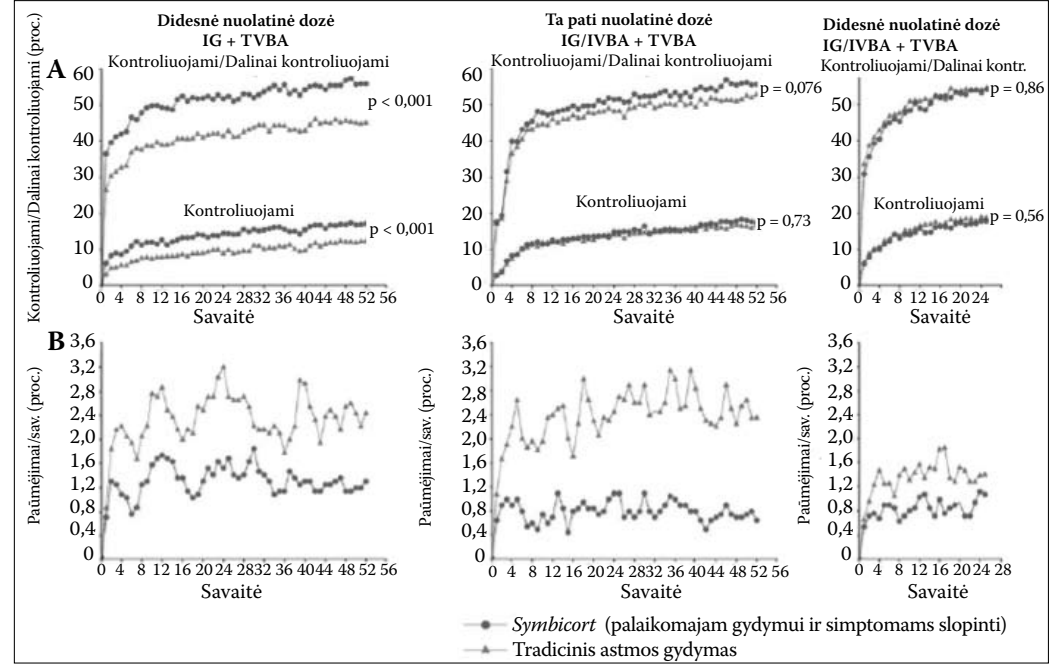

2 pav. KONTROLIUOJAMA/DALINAI KONTROLIUOJAMA ASTMA (A) IR PAÜMĖJIMAI (B) GYDANT SYMBICORT SMART IR TRADICINIU ASTMOS GYDYMO BÜDU

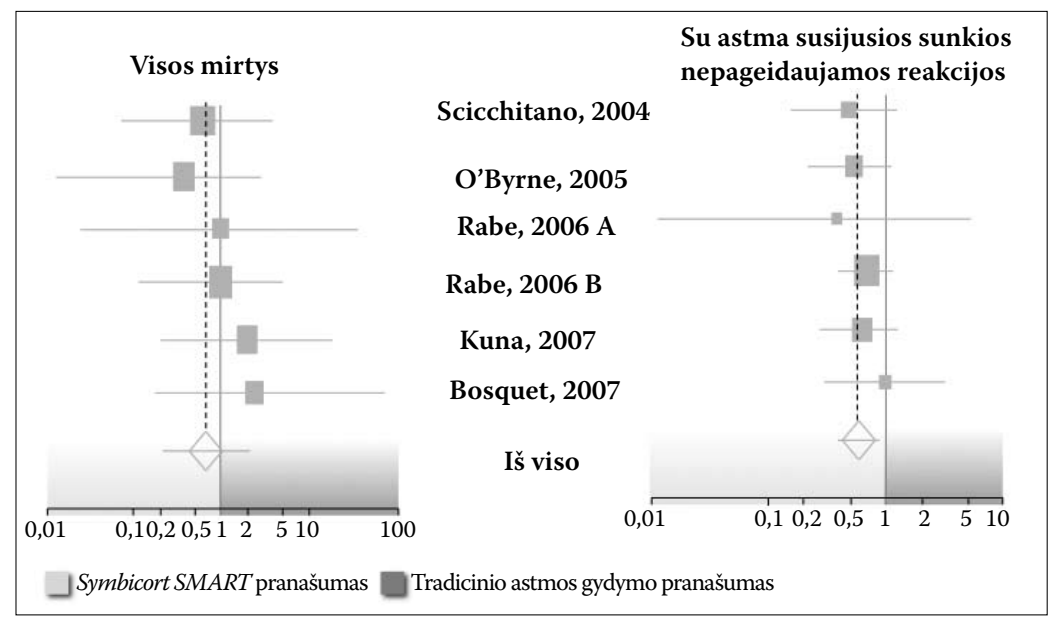

3 pav. SYMBICORT SMART GYDYTŲ PACIENTŲ GRUPĖSE BUVO MAŽIAU MIRČIŲ IR SUNKIŲ SU ASTMA SUSIJUSIŲ NEPAGEIDAUJAMŲ REAKCIJŲ NEI GYDYTŲ TRADICINIU BŪDU

pav.). E. D. Bateman ir kolegu atlikta retrospektyvioji tyrimu, kuriuose buvo taikomas Symbicort SMART metodas, analizè parodè, kad Symbicort SMART ne tik užtikrina esamą kontrolę, bet sėkmingai sumažina ligos keliamą riziką ateityje.

M. R. Sears ir F. Radner atlikta klinikinių tyrimų, kuriuose Symbicort SMART lygintas su tradiciniu astmos gydymo būdu, analizè parodè, kad Symbicort $S M A R T$ metodu skiriamas gydymas ne tik gerai toleruojamas, bet ir yra saugus (3 pav.).

\section{EUROSMART TYRIMAS}

EUROSMART - vienas didžiausių kada nors atliktų astmos klinikinių tyrimų, ì kurị buvo ịtraukta daugiau kaip 8 tūkst. pacientų iš 14 Europos šalių. Šio tyrimo rezultatai buvo plačiai aptarti paskutiniame (2009 m.) Vienoje vykusiame Europos respiratologu sąjungos (ERS) kongrese. EUROSMART tyrimo tikslas buvo ịvertinti Symbicort SMART veiksmingumą, kai budezonido/formoterolio 160/4,5 $\mu \mathrm{g}$ palaikomajam gydymui buvo skiriama po 1 ikkvejpimą 2 kartus per 


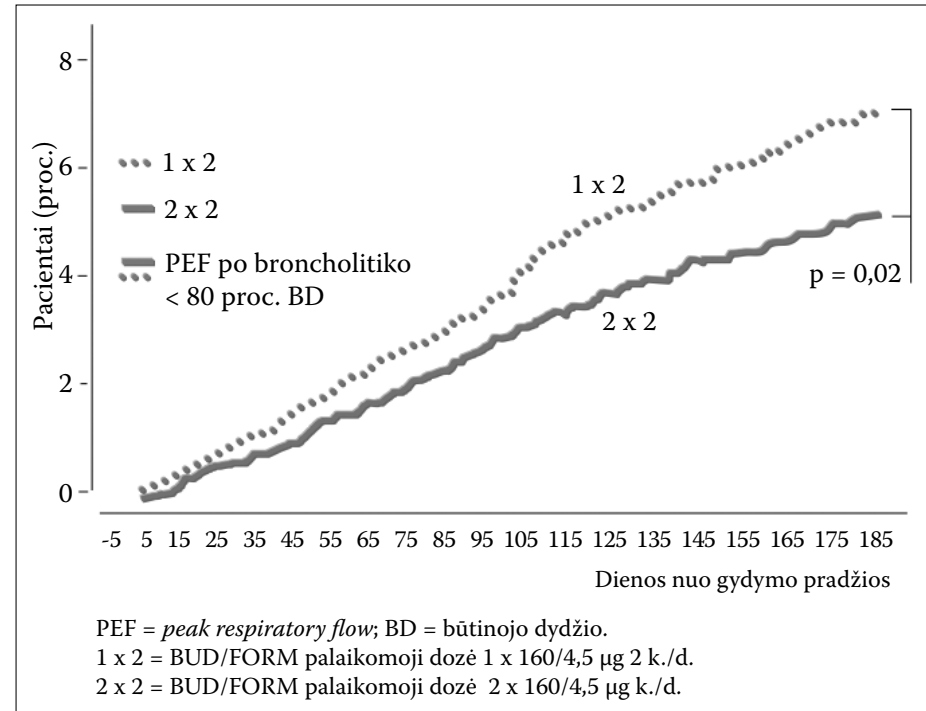

4 pav. SYMBICORT (160/4,5 ug BUDEZONIDO/FORMOTEROLIO) SMART SKIRIANT PALAIKOMAJJA DOZE PO 2 [KVËPIMUS 2 KARTUS PER DIENĄ REIKŠ MINGAI LABIAU PAILGĖJA LAIKAS IKI PIRMO SUNKAUS PAÜMĖJIMO TIEMS PACIENTAMS, KURIŲ PRADINIS PEF PO BRONCHOLITIKO (IKI GYDYMO) BUVO MAŽESNIS KAIP 80 PROC. BÜTINOJO DYDŽIO

dieną ( $1 \times 2$ ) arba po 2 ịkvėpimus 2 kartus per dieną ( $2 \times 2)$; gydymo trukmè -6 mènesiai. Abiejose grupèse pacientu, kurių astma buvo nekontroliuojama, skaičius vertinant pagal astmos kontrolès klausimyną (ACQ) gydant sumažèjo perpus: nuo 61 proc. iki 30 proc. Daugumos pacientu astma buvo gerai kontroliuojama Symbicort SMART $1 \times 2$ palaikomąja doze, tačiau atlikus detalesnę tyrimo duomenų analizę nustatyta, kad geresnị terapini atsaką ì Symbicort SMART 2 x 2 palaikomąją dozę pasiekia tie pacientai, kurių pradinis PEF (iki gydymo) po broncholitiko buvo mažesnis kaip 80 proc. būtinojo dydžio (4 pav.). Šio tyrimo rezultatai sudaro prielaidą pateikti tokią klinikinę rekomendaciją: astma sergantiems pacientams, kurių pradinè plaučiuc funkcija yra blogesnè (pvz., PEF mažesnis kaip 80 proc. būtinojo dydžio) arba nèra patikslinta, pradinè vaisu dozė gydant Symbicort SMART turètų būti 160/4,5 $\mu \mathrm{g}$ budezonido/formoterolio $2 \times 2$ ir pagal poreiki iš to paties inhaliatoriaus esant simptomų.

\section{APIBENDRINIMAS}

Symbicort SMART gydymo metodas padeda užtikrinti ne tik esamą astmos kontrolę (gydant tinkama palaikomąja vaisto doze slopinamas nuolat rusenantis uždegimas), bet ir papildomai vartojant simptomams šalinti iš to paties inhaliatoriaus (vietoj TVBA) slopina uždegimą tada, kai to labiausiai reikia, - beprasidedant paūmèjimui. Taigi gydymas vienu inhaliatoriumi ne tik supaprastina astmos gydymą ir garantuoja optimalią vaisto dozę, bet ir padeda išvengti paūmejjimų - sumažinti riziką ateityje.

Publikaciją remia UAB „AstraZeneca Lietuva“ 1006/01.

\section{SYMBICORT SMART EXPANDS POSSIBILITIES OF ASTHMA CONTROL}

\section{BRIGITA ŠITKAUSKIENE \\ DEPARTMENT OF PULMONOLOGY AND IMMUNOLOGY KAUNAS UNIVERSITY OF MEDICINE}

Keywords: asthma control, Symbicort SMART, exacerbations, "future risk". Summary: Asthma guidelines emphasize both maintaining current control and reducing future risk. The retrospective analysis of Symbicort SMART studies showed that budesonide/formoterol maintenance and reliever therapy achieves good asthma control and reduces exacerbations versus comparators predicts future risk of asthma instability.

\section{LITERATŪRA}

1. Bateman ED, Reddel HK, Eriksson G, et al. Overall asthma control: The relationship between current control and future risk. J Allergy Clin Immunol 2010; 125: 600-608.

2. Reddel HK, Taylor DR, Bateman ED, et al. An official Americal Thoracic Society / European Respiratory Society statement: asthma control and exacerbations. Am J Respir Crit Care Med 2009; 180: 59-99.

3. Global Initiative for Asthma (GINA). Global strategy for asthma management and prevention: NHLBI/WHO workshop report. Bethesda: National Institutes of Health, National Heart, Lung and Blood Institute. Updated 2008. Internetinè prieiga: http://www.ginasthma.com

4. Bateman ED, Bousquet J, Busse WW, et al. Stability of asthma control with regular treatment: an analysis of the Gaining Optimal Asthma control (GOAL) study. Allergy 2008; 63: 932-938.

5. Haughney J, Aubier M, Buhl R, et al. Patient characteristics to determine an appropriate maintenance dose of budesonide/formoterol maintenance and reliever therapy. Abstract presented during the European Respiratory Society Annual Congress, Vienna, Austria, 12-16 September 2009.

6. Sears MR, Radner F. Safety of budesonide/formoterol maintenance and reliever therapy in asthma trials. Respir Med 2009; 103: 1960-1968.

7. Šitkauskienè B. Astmos kontrolè vienu inhaliatoriumi - nauja astmos gydymo strategija. Pulmonologija, imunologija ir alergologija 2007; 2 56-59.

8. Šitkauskienè B. Symbicort SMART - pažangus metodas siekiant astmos

kontrolès. Pulmonologija, imunologija ir alergologija 2008; 2: 39-41.

9. Sakalauskas $R$, Bagdonas $A$, Blažienè $A$, ir kt. Lietuvos vaiku ir suaugusiuju astmos diagnostikos ir gydymo sutarimas. Kaunas 2007; 56 p.

10. Barnes PJ. Scientific rationale for using a single inhaler for asthma control. Eur Respir J 2007; 29: 587-595.

11. Partridge MR, van der Molen T, Myrseth SE, Busse WW. Attitudes and actions of asthma patients on regular maintenance therapy: the INSPIRE study. BMC Pulm Med 2006; 6:13.

12. Salpeter SR, Buckley NS, Ormiston TM, Salpeter EE. Meta-analysis: effect of long-acting beta-agonists on severe asthma exacerbations and asthmarelated deaths. Ann Intern Med 2006; 144: 904-912.

13. O'Byrne PM, Bisgaard H, Godard PP, et al. Budesonide/formoterol combination therapy as both maintenance and reliever medication in asthma. Am J Respir Crit Care Med 2005; 171: 129-136.

14. Rabe KF, Pizzichini E, Stallberg B, et al. Budesonide/formoterol in a single inhaler for maintenance and relief in mild-to-moderate asthma: a randomised, double-blind trial. Chest 2006; 129: 246-256.

15. Lundborg $M$, Wille $S$, Bjermer $L$, et al. Maintenance plus reliever budesonide/formoterol compared with a higher maintenance dose of budesonide/formoterol plus formoterol as reliever in asthma: an efficacy and cost-effectiveness study. Curr Med Res Opin 2006; 22: 809-821.

16. Edwards MR, Johnson MW, Johnston SL. Combination therapy: synergistic suppression of virus-induced chemokines in airway epithelial cells. Am J Respir Cell Mol Biol 2006; 34: 616-624. 